胸腔鏡下肺葉切除術による空洞病変切除後に, 対側肺空洞病変の 縮小をみた肺非結核性抗酸菌症の 1 例

\author{
村田 祥武, 松岡 隆久, 長井信二郎 \\ 松岡 勝成, 植田 充宏, 宮本 好博
}

\begin{abstract}
ב
要 旨

症例は 65 歳, 女性. 肺 Mycobacterium avium complex 感染症（肺 MAC 症）で経過観察されていたが, 胸部 X 線で陰影 の悪化を認め, 当院紹介受診. 胸部 CT で右上葉に大きな空洞病変, 左舌区に空洞病変, 両肺野に小葉中心性の粒状影を認め た. 1 年間, 3 剂併用化学療法を行ったが, 両側とも空洞病変が増大した. 右上葉の病変が主な排菌源であると考え, 胸腔鏡 下右上葉切除術を施行した. 術後も化学療法を継続し, 1 年後の胸部 CT では粒状影の増悪はなく, 左空洞病変は縮小した. 両側肺に空洞病変を有したが, 主な排菌源を低侵襲手術で切除することによって病勢が安定し, 対側空洞病変の改善も得ら れたものと思われた。
\end{abstract}

索引用語 : 肺非結核性抗酸菌症, 空洞病変, 胸腔鏡下肺葉切除

pulmonary nontuberculous mycobacteriosis, cavitary lesion, lobectomy under video-assisted thoracoscopic surgery

はじめに

一般的に, 肺非結核性抗酸菌症 (pulmonary nontuberculous mycobacteriosis：pNTM）に対する外科的治療の 適応は, 化学療法にても排菌が停止しない場合, 排菌が 停止しても空洞病変 - 気管支拡張病変が残存し再燃が危 惧される場合, 喀血・繰り返す気道感染・混合感染があ る場合などとされており, 一側肺に病変が限局している ものが良い適応とされている ${ }^{1-4)}$. 今回我々は, 内服治療に も関わらず増悪する両側肺空洞病変を認めた肺 Mycobacterium avium complex 感染症（肺 MAC 症）に対し て, 主病巣である大きな空洞病変の切除により, 対側病 変の改善を認めた 1 例を経験したので報告する.

独立行政法人国立病院機構姫路医療センター呼吸器外科 原稿受付 2014年 5 月 2 日 原稿採択 2014年 8 月 1 日 本論文の要旨は第 30 回日本呼吸器外科学会にて発表した.
症例

患 者：65 歳, 女性.

主 訴: 胸部異常陰影.

既往歴 : 29, 32 歳時, 帝王切開術. 35 歳時, 右卵巣囊 腫摘出術.

喫煙歴：なし。

現病歴 : 2007 年 3 月より, 肺 MAC 症で近医に通院し ていたが, 2011 年 4 月の胸部 X 線（Fig. 1）で陰影の増 悪を認めたため, 当院紹介受診となった．来院時の胸部 CT (Fig. 2) で右上葉・左舌区に空洞病変, 右上葉や舌区 を中心に気管支拡張，小葉中心性の粒状影を認めた。同 月より rifampicin $450 \mathrm{mg} /$ 日, ethambutol $500 \mathrm{mg} /$ 日, clarithromycin $800 \mathrm{mg} /$ 日による化学療法（RECAM）を 行ったが, 2012 年 5 月の胸部 CT で右上葉・左舌区の空 洞病変が増大した. 内科的治療のみでのコントロールが 困難であったため, 主病巣と思われる右上葉空洞病変の 切除目的で同月に当科入院となった.

入院時現症：身長 $151.0 \mathrm{~cm}$, 体重 $38.0 \mathrm{~kg}, \quad \mathrm{SpO} 297 \%$ 
(Room air).

血液検査所見：WBC $4800 / \mu \mathrm{l}, \mathrm{RBC} 491$ 万/ $\mu \mathrm{l}, \mathrm{Hb} 13.8$ $\mathrm{g} / \mathrm{dl}$, Plt 19.1 万 $/ \mu \mathrm{l}$, PT $114 \%$, APTT $27.1 \mathrm{sec}$, AST $32 \mathrm{U} / 1$, ALT 24 U/1, LDH 213 U/1, BUN 16 mg/dl, Cr $0.73 \mathrm{mg} / \mathrm{dl}, \mathrm{Na} 142 \mathrm{mEq} / \mathrm{l}, \mathrm{K} 4.2 \mathrm{mEq} / \mathrm{l}, \mathrm{Cl} 103 \mathrm{mEq} / \mathrm{l}$, CRP $0.66 \mathrm{mg} / \mathrm{dl}$, TP $7.8 \mathrm{~g} / \mathrm{dl}$.

術前呼吸機能検査 : VC $1.92 \mathrm{~L}, \% \mathrm{VC} 83.5 \%, \mathrm{FEV}_{1} 1.51$

$\mathrm{L}, \% \mathrm{FEV}_{1} 86.8 \%, \mathrm{FEV}_{1 \%} 75.1 \%$.

術前胸部 $\mathbf{X}$ 線所見 : 右上肺野に空洞を伴う浸潤影あ

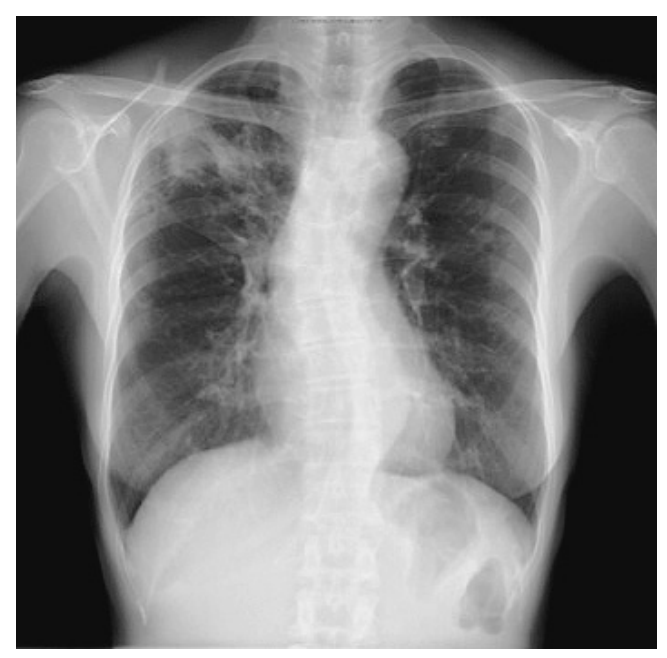

Fig. 1 A chest radiograph before chemotherapy showed a cavity in the right upper lung field and a nodular shadow in the left middle lung field.
り，左中肺野にも空洞陰影あり（Fig. 3）.

胸部 CT : 空洞病変は左右ともに増大し, 両側下葉の 一部の範囲で小葉中心性陰影が増大した（Fig. 4).

手術所見：左側臥位に体位を固定し，完全鏡視下で手 術を行った，右上葉の空洞部分近傍に胸膜癒着あり。そ の他にも, 上葉縦隔側・中葉縦隔側・中葉先端に索状癒 着を認めた. 空洞部分の癒着は, 壁側胸膜外で剥離した. 上下葉間も癒着していたが, 完全分葉であり剥離できた. 肺動脈の周囲組織は肥厚していたが剥離可能で結紮処理 できた，右上葉肺静脈，上中葉間は自動縫合器で切離し た. 上葉支周辺には，著明に腫大したリンパ節が見られ， 気管支動脈も発達していたが鏡視下に肺門を処理し，自 動縫合器で上葉支を切断した後, 右上葉を切除した. 右 上葉支断端は被覆しなかった。手術時間：93 分, 出血 量 : 少量であった，空洞内には膿汁を認め，抗酸菌培養 $(+)$, PCR-M. Avium $(+)$, 病理で類上皮細胞性肉芽腫 を認めた。

術後経過: 術後 2 日目から 3 剂併用化学療法を再開し た．術後 4 日目に胸䏶ドレーンを抜去し，術後 5 日目に 独歩退院となった. 現在, 術後 1 年が経過して化学療法 継続中であるが, 胸部 CT で粒状陰影の増悪はなく, 左空 洞病変の縮小を認めた（Fig. 5).

\section{考察}

肺 MAC 症 は, Mycobacterium avium と Mycobacterium intracellulareによる肺感染症の総称で, 日本では
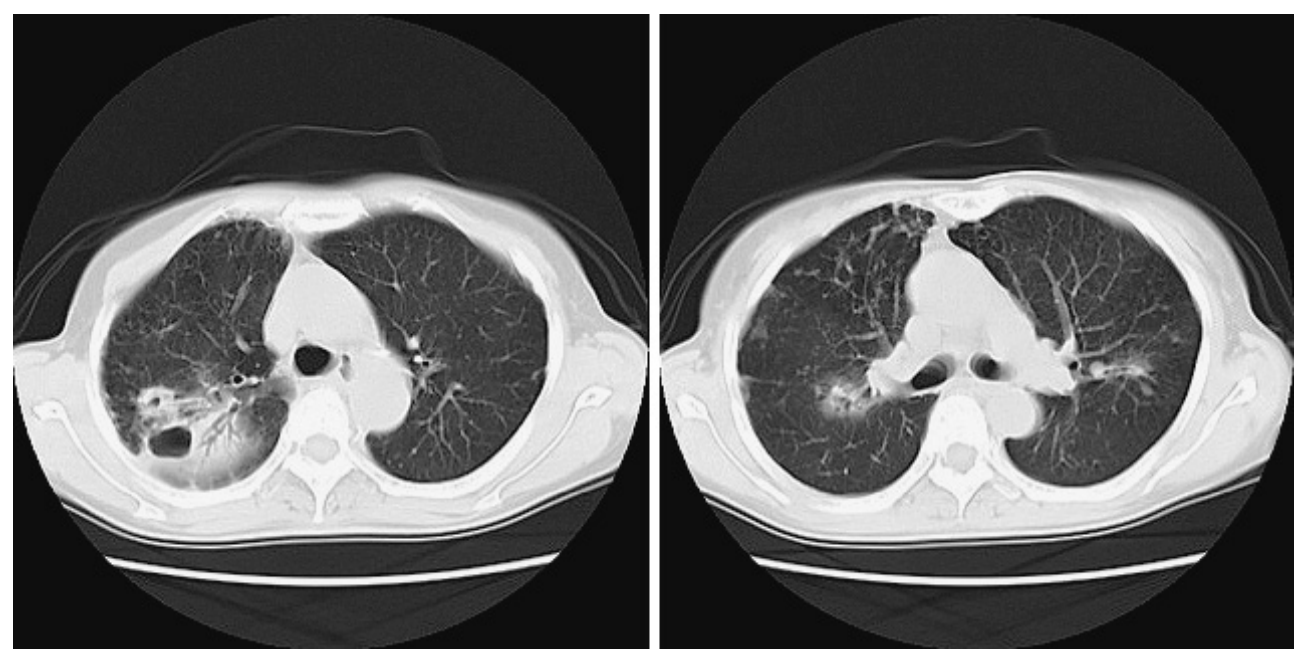

Fig. 2 Chest computed tomography before chemotherapy showing a large cavity in the right upper lobe and a small lesion in the left upper lobe. 
肺 NTM 感染症の 8 割を占める. 近年, 肺 MAC 症患者は 増加傾向にあり，特に日本において罹患率は高い. 1997 年の罹患率は人口 10 万対 3.52 であり，現在は $6.0 \sim 8.0$ と推定されている1 ${ }^{1}$.

肺 MAC 症の治療としては, clarithromycin を中心と した多剤併用化学療法が有効とされているが, 現状では 内科的治療のみでの完治は困難で, 治療に反応せず進行 性に悪化する症例も存在する．特に空洞や気管支拡張な どの気道構造破壊性病巣を伴う症例では, 内科的治療の

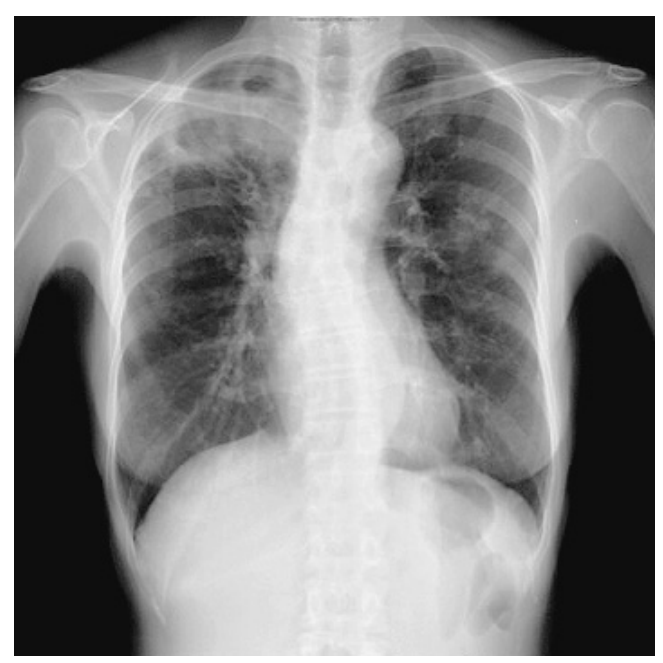

Fig. 3 A preoperative chest radiograph showed that the large cavity in the right upper lung field and nodular shadow in the left middle lung field had enlarged.
みで根治させることは非常に困難であり，外科的切除が 有効であると報告されている ${ }^{1-4)}$.

外科的治療の適応としては，(1)排菌源または排菌源と なりうる主病巣が明らかで, 化学療法無効または再排菌 例，もしくは画像上，病巣の拡大または悪化傾向がみら れるか予想されるもの，(2)排菌が停止しても空洞病変や 気管支拡張病変が残存し, 再発再燃が危惧されるもの, (3)大量排菌があり病変が急速に進行するもの, (4)喀血, 慢性気道感染，アスペルギルス混合感染等の合併例，(5) 70 歳程度までで, 心肺機能その他の評価で耐術であるも の, とされており，一側肺に限局した病巣が良い適応と なる。しかし，対側肺や同側他葉の散布性小結節や粒状 影のある症例でも手術適応となり，それらの小結節や粒 状影は必ずしも切除の対象としなくてもよい2). 大量排菌 源となる病変を摘除し，菌量を減少させることで病勢を 安定させ，進行を抑制できる場合があるとされており， 渡辺ら, Hamada らも両側肺病変の患者に対して, 主排菌 源と考えられる空洞病変を切除することで, 対側病変が 改善した例を報告している ${ }^{3.5)}$. 本症例は，右上葉の大き な空洞病変以外に左肺舌区にも小さな空洞病変を認め, 1 年間の化学療法 (RECAM) にも関わらず, 両側空洞病 変が拡大した。 American Thoracic Society ${ }^{4)}$ や日本結核 病学会 ${ }^{2}$ による肺非結核性抗酸菌症外科治療ガイドライ ンでは，両側空洞病変に対しての手術適応の記載はない が，化学療法単独で空洞病変の進行を抑制することは非 常に難しいとされている. 肺 MAC 症患者において, 排菌
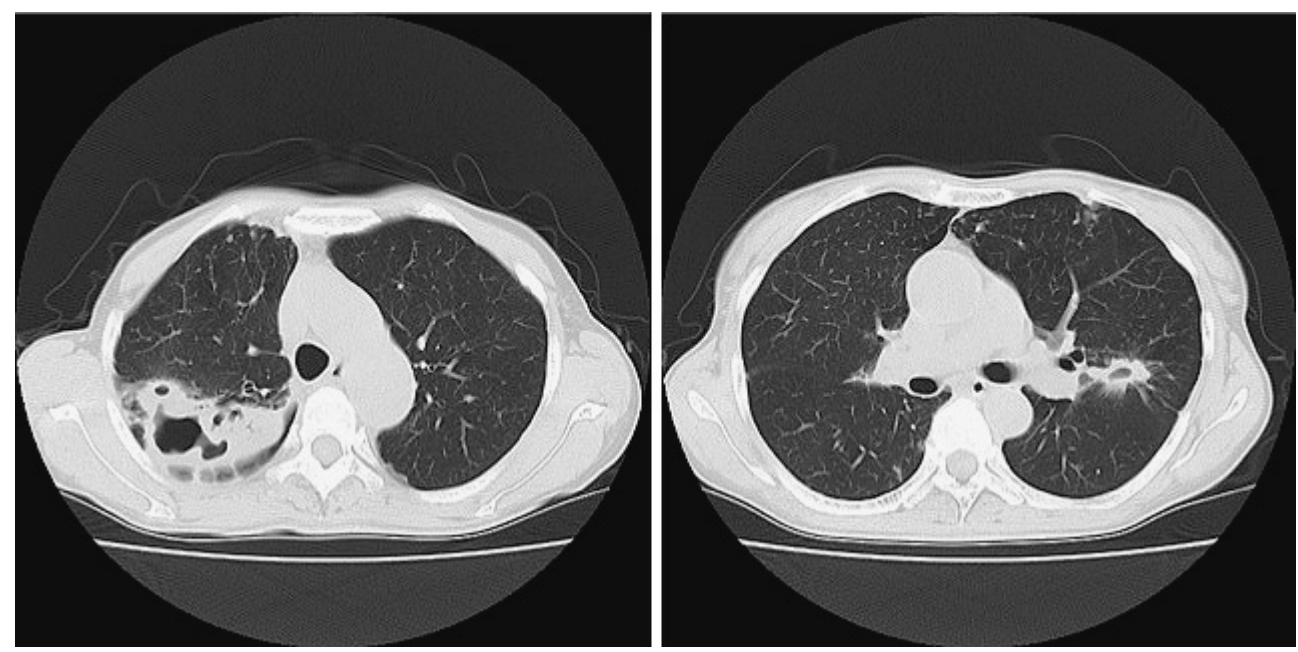

Fig. 4 Preoperative chest computed tomography showed that the large cavity in the right upper lobe had enlarged and a small cavity in the left upper lobe had appeared. 

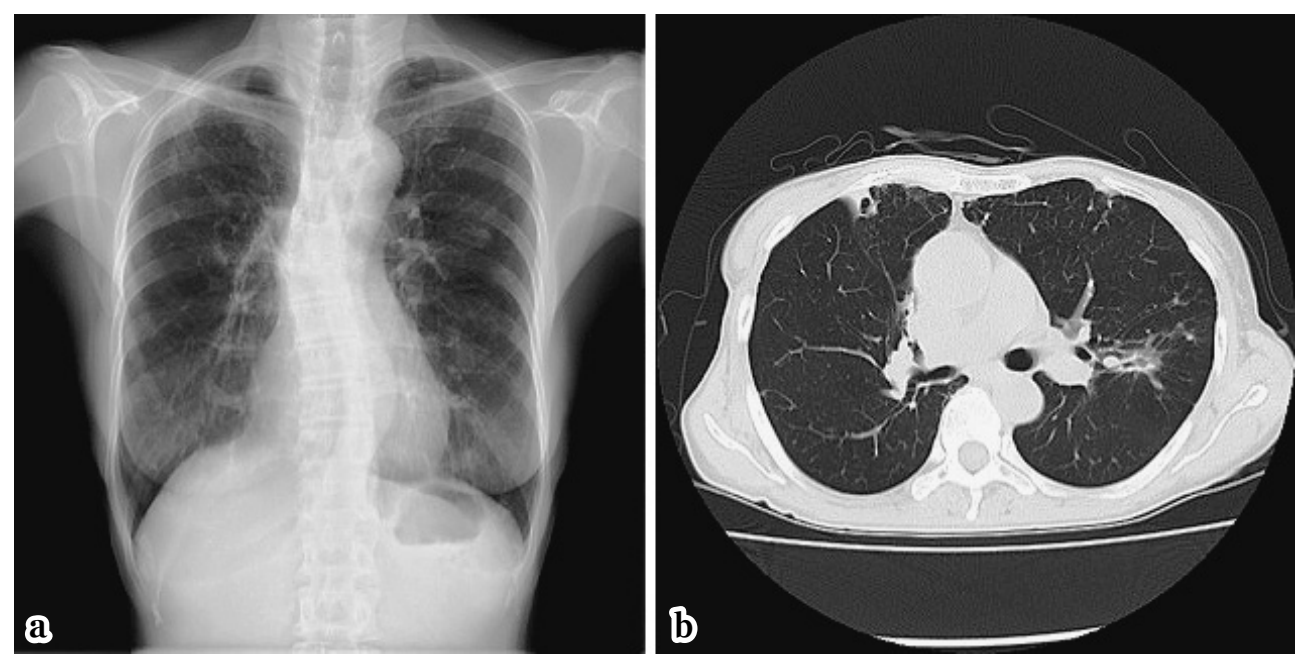

Fig. 5 Postoperative chest radiograph (a) and computed tomography (b) showed that the cavity in the left upper lobe had decreased in size.

は気管支拡張症・肺小結節病変で少なく, 空洞病変で多 いと考えられている ${ }^{6}$. 今回の症例では, 右肺空洞病変が 左病変に比べて大きく, 増大傾向にあるため, 菌量の多 い活動性のある主病巣と判断した. 主病巣の切除による 進行抑制・病勢安定を期待し, 胸腔鏡下右上葉切除術を 施行した. 術前の内科的治療にも関わらず両側空洞病変 は増大していたが, 右空洞病変の切除と術後化学療法に より左空洞病変が縮小した. Hamada らも, 化学療法によ り排菌は停止したが右上葉に空洞病変・両側に散在性結 節病変が残存した症例に対して, 右上葉切除と化学療法 を施行し, 両側結節病変が消失したと報告している ${ }^{3}$. 機 序は明確ではないが, 本症例でも空洞病変の切除により 進行抑制だけでなく対側病変の縮小が得られた。

慢性炎症性疾患に対する胸腔鏡下手術は, 広範囲な癒 着や血管周囲の組織肥厚, リンパ節腫大, 気管支動脈の 増生・拡張などがあり, 技術的に困難を伴うことが多く, 開胸に移行する例も存在する ${ }^{7)}$. しかし, 胸腔鏡下手術は 開胸手術と比較して, 術後疼痛の軽減や術後合併症発生 率の低下, 術後入院期間の短縮, 免疫応答の軽減などが 報告されている ${ }^{8,9)}$. 本症例も胸腔鏡下に右上葉切除が施 行でき, 術後合併症もなく順調に経過し, 速やかに化学 療法を再開できた。

肺 $\mathrm{MAC}$ 症で, 両側空洞性病変の手術報告例が少ない ため, 外科的治療に関して一定の指針はない.しかし, 本症例のように，主となる排菌源が一葉に限局しており 切除可能である場合には, 化学療法と外科的治療を組み
合わせることで良好な経過をとる症例も存在すると思わ れた。

\section{結 語}

両側肺に空洞病変を認めた非結核性抗酸菌症に対し て, 右上葉空洞の切除により左肺空洞の改善をみた 1 例 を経験したので報告した.

\section{利益相反}

本論文について申告する利益相反はない.

\section{文献}

1. 倉島篤行, 中川 拓, 小橋吉博, 蛇澤 晶, 白石裕治, 鈴 木克洋. 非結核性抗酸菌症フロンティア. 日本胸部臨床 2009; 68: 999-1060.

2. 倉島篤行, 鈴木克洋, 綱島 優, 大内基史, 小川賢二, 加 治木彰, 他. 肺非結核性抗酸菌症に対する外科治療の指 針. 結核 2008; 83: 527-8.

3. Hamada N, Kawata N, Shibayama T, Makihara S, Tada A, Soda R. Non-localized Mycobacterium avium Lung Disease Successfully Treated with Lobectomy and Chemotherapy. Intern Med 2010; 49: 1233-6.

4. Griffith DE, Aksamit T, Brown-Elliott BA, Catanzaro A, Daley C, Gordin F, et al. An official ATS/IDSA Statement: Diagnosis, Treatment, and Prevention of Nontuberculous Mycobacterial Diseases. Am J Respir Crit 
Care Med 2007; 175: 367-416.

5. 渡辺真純, 野守裕明, 長谷川直樹, 石坂彰敏. 非結核性抗 酸菌症に対する肺切除術. 結核 2010; 85: 201-4.

6. Lynch DA, Simone PM, Fox MA, Bucher BL, Heinig MJ. CT Features of Pulmonary Mycobacterium avium Complex infection. J Comput Assisted Tomogr 1995; 19: 35360.

7. Mitchell JD, Yu JA, Bishop A, Weyant MJ, Pomerantz M. Thoracoscopic Lobetcomy and Segmentectomy for Infectious Lung Disease. Ann Thorac Surg 2012; 93: 1033-
40.

8. Paul S, Altorki NK, Sheng S, Lee PC, Harpole DH, Onaitis MW, et al. Thoracoscopic lobectomy is associated with lower morbidity than open lobectomy. J Thorac Cardiovasc Surg 2010; 139: 366-78.

9. Villamizar NR, Darrabie MD, Burfeind WR, Petersen RP, Onaitis MW, Toloza E, et al. Thoracoscopic lobectomy is associated with lower morbidity compared with thoracotomy. J Thorac Cardiovasc Surg 2009; 138: 419-25.

\title{
A case of pulmonary nontuberculous mycobacteriosis with bilateral cavitary lesions improved by thoracoscopic lobectomy and chemotherapy
}

\author{
Yoshitake Murata, Takahisa Matsuoka, Shinjiro Nagai \\ Katsunari Matsuoka, Mitsuhiro Ueda, Yoshihiro Miyamoto \\ Department of Thoracic Surgery, National Hospital Organization Himeji Medical Center
}

A 65-year-old woman was referred to our hospital for pulmonary nontuberculous mycobacterial infection. Chest CT showed cavities in both upper lobes. Even though she underwent antimycobacterial chemotherapy for a year, the cavities enlarged. We performed a right upper lobectomy under video-assisted thoracoscopic surgery, because a large cavity in the right upper lobe was the main source of bacterial discharge. A year after the operation, a small cavity in the left lung showed improvement on chest CT. 